\title{
A new Ecuadorian species of the rare Neotropical caddisfly genus Amphoropsyche Holzenthal (Trichoptera, Leptoceridae)
}

\author{
Ralph W. Holzenthal', Blanca Ríos-Touma² \\ I University of Minnesota, Department of Entomology, 1980 Folwell Ave., 219 Hodson Hall, St. Paul, Minne- \\ sota 55108 U.S.A. 2 Universidad de las Américas, Facultad de Ingenierias y Ciencias Agropecuarias, Unidad \\ de Investigación en Biotecnología y Medio Ambiente-BIOMA-, Campus Queri, Calle José Queri, Edificio \#8, \\ PB, Quito, Ecuador \\ Corresponding author: Ralph W. Holzenthal (holze001@umn.edu) \\ Academic editor: P. Stoev | Received 30 August 2016 | Accepted 2 December 2016 | Published 13 December 2016 \\ http://zoobank.org/9DFBA8A1-4E6B-42A0-99A0-9FF4C8BF79E3 \\ Citation: Holzenthal RW, Ríos-Touma B (2016) A new Ecuadorian species of the rare Neotropical caddisfly genus \\ Amphoropsyche Holzenthal (Trichoptera, Leptoceridae). ZooKeys 640:59-67. https://doi.org/10.3897/zookeys.640.10344
}

\begin{abstract}
A new species of the rare long-horned caddisfly genus Amphoropsyche Holzenthal is described from Ecuador, bringing the number of species known from the genus to 15 . All species are very regional in their distributions and known only from very few specimens. The new species, Amphoropsyche real, is similar to a number of previously described species from Colombia (A. ayura, A. cauca, A. flinti, A. quebrada, and A. stellata) and Ecuador ( $A$. napo and $A$. tandayapa). The males can be distinguished from the others by features of segment $\mathrm{X}$ of the male genitalia, especially the prominent midlateral and subapicodorsal spinelike setae. An updated taxonomic key to males of the genus is provided.
\end{abstract}

\section{Keywords}

Trichoptera, caddisfly, Neotropics, new species, key to species, rare, endemic, Andes 


\section{Introduction}

The long-horned caddisfly genus Amphoropsyche Holzenthal, 1985 is endemic to the Neotropical Region where it now contains 15 described species (Table 1), including a new species described herein. While widely distributed, its species are among the rarest of the Neotropical caddisflies. Only a few specimens are known to exist in museum collections and almost all of the specimens known to us are housed in 2 insect drawers, 1 at the University of Minnesota and 1 at the Smithsonian Institution. Whether the species are habitat specialists or do not fly to UV light traps set at dusk (the most common method for collecting adult caddisflies) is unknown. On one occasion, the senior author netted individuals of $A$. woodruffi woodruffi Flint and Sykora, swarming during mid-day over a small, shallow stream in Venezuela. Otherwise, they are collected 1 or 2 at a time from lights or from Malaise traps. Larvae are known only for one species, A. insularis (Flint), recorded from the sandy bottom of a pool in a small stream on the Lesser Antillean island of Dominica. Larvae build cases of sand grains (Holzenthal 1986). Adults of the other species also seem to be associated with small, gravel-bottomed streams in hilly or mountainous areas. Adult males contain interesting pheromone dispersing structures on the genitalia (Botosaneanu 1991). In this paper we describe the 15th known species in the genus and the 3rd recorded from Ecuador. The new species is known from 1 male and 2 female specimens. The previously most recently described species, $A$. tandyapa Holzenthal and Rázuri-Gonzales, also from Ecuador, is known from only the male holotype. These discoveries further corroborate Holzenthal's (1986) prediction that the northern Andes harbor a rich fauna of these very rare, enigmatic icons of the Neotropical caddisfly fauna.

\section{Material and methods}

This species is based on material collected by the authors and their colleagues during an ongoing inventory of the Trichoptera of Ecuador. Specimens were attracted to a UV light placed over a shallow, white plastic pan filled with $80 \%$ ethyl alcohol placed next to a small, gravel stream. Techniques and procedures used in the preparation and examination of the specimen were outlined by Blahnik and Holzenthal (2004) and Blahnik et al. (2007). The illustrations of the genitalia were prepared from pencil sketches made with the aid of a drawing tube mounted on an Olympus BX41 compound microscope. The pencil sketches were then scanned and placed into an Adobe Illustrator (version CC, Adobe Systems, Inc.) document, to serve as a template, and then traced to create a vector graphic illustration. A graphic tablet and pen (Intuous ${ }^{\mathrm{TM}}$, Wacom Technology Co.) facilitated careful tracing of the original image.

Terminology used in describing male and female genitalia follows that of Holzenthal $(1985,1986)$. The updated taxonomic key is modified from that published by Holzenthal and Rázuri-Gonzales (2011) and is based on published illustrations and descriptions of the male genitalia (Holzenthal 1985, 1986; Botosaneanu 1990; Flint and Sykora 1993, 
Table I. Species, distributions, and published records of known individuals in the caddisfly genus Amphoropsyche (Leptoceridae). HT = holotype, PT = paratype, ${ }^{*}=$ immature stages known.

\begin{tabular}{|c|c|c|c|}
\hline Species & Distribution & $\begin{array}{c}\text { Known individuals in } \\
\text { literature }\end{array}$ & Additional references \\
\hline aragua Holzenthal, 1985 & Venezuela & male HT, 5 male PTs & - \\
\hline ayura Holzenthal, 1985 & Colombia & male HT, 1 female PT & Flint 1991 \\
\hline cauca Holzenthal, 1985 & Colombia & male HT & Flint 1991 \\
\hline choco Holzenthal, 1985 & Colombia & male HT & - \\
\hline flinti Holzenthal, 1985 & Colombia & male HT & Flint 1991 \\
\hline $\begin{array}{l}\text { insularis (Flint, 1968) } \\
\text { Brachysetodes* }\end{array}$ & $\begin{array}{c}\text { Dominica, Guadeloupe, } \\
\text { Martinique }\end{array}$ & $\begin{array}{c}\text { male HT, } 48 \text { male, } \\
21 \text { female PTs, } 3 \text { larvae, } \\
1 \text { pupa; } 4 \text { additional } \\
\text { specimens }\end{array}$ & $\begin{array}{c}\text { Holzenthal 1985, 1986; } \\
\text { Flint and Sykora 1993; } \\
\text { Botosaneanu 1994; Bo- } \\
\text { tosaneanu and Thomas } \\
2005\end{array}$ \\
\hline janstockiana Botosaneanu, 1990 & St. Vincent, Mustique[?] & male HT, 3 male PTs & $\begin{array}{l}\text { Botosaneanu 1991; Flint } \\
\text { and Sykora } 1993\end{array}$ \\
\hline napo Holzenthal, 1985 & Ecuador & male HT & - \\
\hline quebrada Holzenthal, 1985 & Colombia & male HT, 2 female PTs & Flint 1991 \\
\hline $\begin{array}{l}\text { real Holzenthal \& } \\
\text { Ríos-Touma, sp. n. }\end{array}$ & Ecuador & male HT, 2 female PTs & - \\
\hline refugia Holzenthal, 1985 & Venezuela & $\begin{array}{c}\text { male HT, } 1 \text { male, } \\
1 \text { female PTs }\end{array}$ & - \\
\hline spinifera Holzenthal, 1986 & Bolivia, Peru & $\begin{array}{c}\text { male HT, } 3 \text { male, } \\
1 \text { female PTs }\end{array}$ & Flint 1996 \\
\hline stellata Holzenthal, 1985 & Colombia & male HT & - \\
\hline $\begin{array}{l}\text { tandayapa Holzenthal } \\
\text { \& Rázuri-Gonzales, } 2011\end{array}$ & Ecuador & male HT & - \\
\hline $\begin{array}{l}\text { woodruffi multispinosa } \\
\text { Botosaneanu, 1993, in } \\
\text { Botosaneanu \& Alkins-Koo, } 1993\end{array}$ & Trinidad & $\begin{array}{l}\text { male HT, } 3 \text { female PTs; } \\
9 \text { additional specimens }\end{array}$ & $\begin{array}{c}\text { Botosaneanu and Sakal } \\
\text { 1992; Flint } 1996\end{array}$ \\
\hline $\begin{array}{l}\text { woodruffi woodruffi } \\
\text { Flint \& Sykora, } 1993\end{array}$ & Grenada, Venezuela & $\begin{array}{c}\text { male HT; } 40 \text { additional } \\
\text { specimens }\end{array}$ & Flint 1996 \\
\hline
\end{tabular}

Botosaneanu and Alkins-Koo 1993; Flint 1996 [these papers can be downloaded from the Trichoptera Literature Database at www.trichopteralit.umn.edu to facilitate comparisons]). The types are deposited in the University of Minnesota Insect Collection (UMSP), St. Paul, Minnesota, USA, and the Museo Ecuatoriano de Ciencias Naturales (MECN), Quito, Ecuador. The specimens are preserved in $80 \%$ ethyl alcohol.

\section{Systematics}

\section{Genus Amphoropsyche Holzenthal}

Amphoropsyche Holzenthal, 1985:255 [Type species: Brachysetodes insularis Flint 1968, original designation]. — Holzenthal, 1985:254 [revision]. — Holzenthal, 1986:251 [larva, pupa]. —Holzenthal and Rázuri-Gonzales, 2011:63 [key to species]. 


\section{Amphoropsyche real Holzenthal \& Ríos-Touma, sp. n.} http://zoobank.org/4D4D3E54-69B4-4E43-A8BE-3052E60F1F95

Figs 1, 2

Diagnosis. This new species is most similar to $A$. napo and $A$. tandayapa, from Ecuador, and the Colombian species $A$. ayura, A. cauca, A. finti, A. quebrada, and $A$. stellata. All of these species share tergum X bearing a mesal process and paired, lateral processes of various forms. The new species is the only one with the combination of long, spatulate mesal process and the lateral processes bearing both a prominent midlateral and a prominent subapicodorsal spinelike seta. In addition, $A$. ayura, $A$. napo, A. quebrada, A. stellata, and $A$. tandayapa have prominent parameres in the phallus, lacking in $A$. real, sp. n., while $A$. cauca, $A$. flinti, and $A$. tandayapa have a baso- or mesoventral process on the inferior appendages not present in the new species.

Description. Male. Forewing length $5.0 \mathrm{~mm}$. Body and legs stramineous, wings light brown, apical 1/5th light cream (specimen preserved in $80 \%$ ethyl alcohol). Genitalia as in Fig. 1A-D. Segment IX annular, sternum with anterior part not extended anteriorly (Fig. 1A). Segment X composed of a single mesal process and pair of lateral processes (Fig. 1A-B); mesal process long, spatulate, apex rounded (Fig. 1B); lateral process broadly crescent shaped, bearing large lateral spinelike seta at midlength and large subapicodorsal spinelike seta; apically lateral process with about 6-8 small, but prominent setae (Fig. 1A). Preanal appendages large, oval, fused basally but divided apically to $1 / 2$ their lengths (apical emargination acute); with large reticulate internal gland and small subapicoventral pore (Fig. 1A-B); apically with pair of asymmetrical, membranous dorsomesal processes, left process large bulbous, right process short (Fig. 1B). [It is highly likely that this asymmetry was caused by a malformation of one or the other or both processes. These processes may be prone to developmental abnormalities.] Inferior appendage with 1st article narrow, elongate, without basoventral projection, instead base short, bulbous and at right angle to straight apical portion of 1 st article when viewed ventrally, bearing 2 small spinelike setae on posterior face (Fig. 1A, C); 1st article ending in a bulbous apex, bearing subterminal tuft of closely appressed setae emerging from membranous pocket; 2 nd article of inferior appendage elongate, thin, slightly curved inwards in ventral view, apex slightly truncate; 2 nd article fused to 1 st article at base (or articulation not apparent) (Fig. 1C). Phallic apparatus (Fig. 1D) with phallobase well developed, with sclerotized apicolateral projection on each side, bearing stout apical spine; parameres absent; endothecal membranes well developed, apparently capable of articulation at midlength [these membranes were evaginated by the clearing process]; phallotremal sclerite well developed, structure as illustrated in Fig. 1D, but difficult to discern on specimen.

Female. Forewing length $6.0 \mathrm{~mm}(\mathrm{n}=2)$. Color and structure similar to male's (specimens preserved in $80 \%$ ethyl alcohol). Genitalia as in Fig. 2A-D. Abdominal tergum IX + X very slightly excised apicomesally, tergum basally with small moundlike mesal protuberance; dorsomesally slightly excised along length. Appendages of 


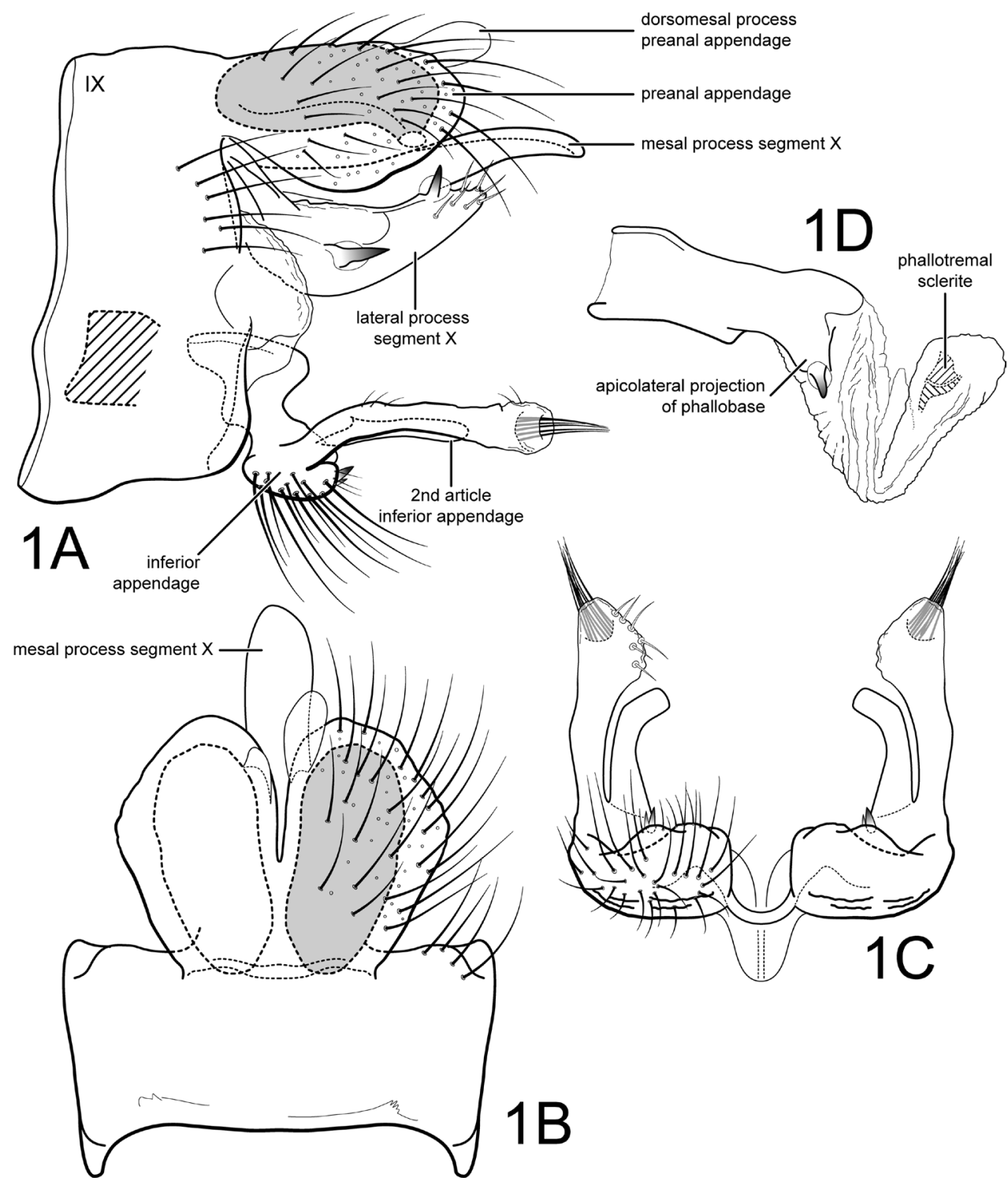

Figure I. Amphoropsyche real, new species. Male genitalia A lateral B segments IX-X, dorsal C inferior appendages, ventral $\mathbf{D}$ phallus, lateral. IX = abdominal segment IX.

segment $\mathrm{X}$ absent (or highly reduced), apparent only as slightly raised, dorsolateral setose areas. Valves posterolateral, quadrate, covered with short setae. Vulvar scale thin, narrow in lateral view, round in dorsal view with slight mesal excavation. Sternum IX laterally forming pocketlike structure in pleural region (probably receptacle for apex of male inferior appendage). Vaginal apparatus (spermathecal sclerite complex) (see Fig. 2C, D) with broad, posterior base bearing central "keyhole-shaped" structure; 


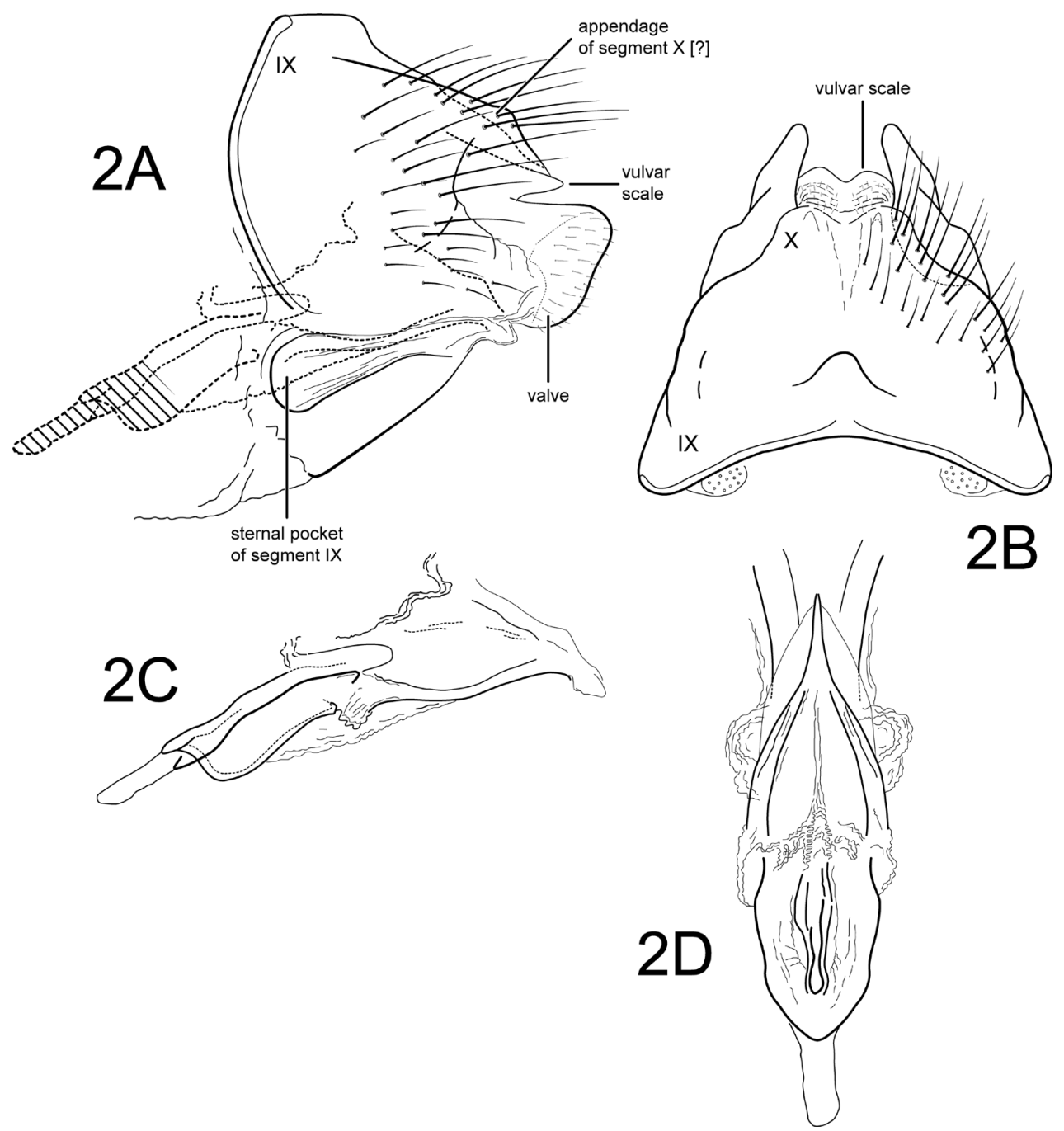

Figure 2. Amphoropsyche real, new species. Female genitalia A lateral B segments IX-X, dorsal C vaginal apparatus, lateral $\mathbf{D}$ vaginal apparatus, ventral. IX = abdominal segment IX, $\mathrm{X}=$ abdominal segment $\mathrm{X}$.

middle region to apex with narrow lightly sclerotized plates and 2 dorsal membranous rounded mounds.

Holotype. Male. ECUADOR: Morona-Santiago: Macas, small gravel stream (Wallace/Real property), $02.20299^{\circ} \mathrm{S}, 078.08539^{\circ} \mathrm{W}$, el. $1076 \mathrm{~m}, 27 . i .2015$, Holzenthal, Huisman, Ríos-Touma, Amigo (UMSP000114167) (UMSP). Paratypes: same data as holotype, 2 females (UMSP, MECN).

Etymology. Named for the family of RhoAnn Wallace and Galo Real and their children, Aster, Diem, and Luna, in recognition of their hospitality, friendship, and stewardship of the land where this species was collected. 


\section{Revised key to males of Amphoropsyche (modified from Holzenthal and Rázuri- Gonzales 2011)}

$1 \quad$ Preanal appendages completely (Holzenthal 1985, figs 8B, 10B; Flint and Sykora 1993, fig. 20) or almost completely fused medially (if the latter, apical emargination shallow, obtuse) (Holzenthal and Rázuri-Gonzales 2011, fig. 1B; Holzenthal 1985, fig. 3B)

- Preanal appendages not fused medially, divided to $1 / 3$ to $2 / 3$ of their length (apical emargination acute) (Fig. 1B; Holzenthal 1985, figs 5B, 6B)..........6

2(1) Preanal appendages with dorsomesal process or processes (Holzenthal 1985, figs $8 \mathrm{~B}, 10 \mathrm{~B})$

- Preanal appendages without dorsomesal process or processes (Holzenthal 1985, figs 3A-D).

A. insularis

3(2) Dorsomesal processes of preanal appendages very short, digitate, not exceeding length of preanal appendage (Holzenthal and Rázuri-Gonzales 2011, figs 1A-D); dorsomesal processes of preanal appendages not sclerotized

A. tandayapa

- $\quad$ Dorsomesal process or processes of preanal appendages long, ca. length of preanal appendage (Holzenthal 1985, figs 8A, 10A; Flint and Sykora 1993, fig. 18); dorsomesal processes of preanal appendages sclerotized 4

4(3) Second article of inferior appendages elongate, narrow (Holzenthal 1985, fig. $8 \mathrm{~A})$ 5 Second article of inferior appendages short (Flint and Sykora 1993, figs 1820; Botosaneanu and Alkins-Koo 1993, figs 97-101)

A. woodruffi

5(4) Dorsomesal process of preanal appendages bifid in dorsal view; ventral subterminal portion of phallobase serrate (Holzenthal 1985, figs 8A-D)

A. refugia

Dorsomesal process of the preanal appendages entire in dorsal view; ventral subterminal portion of phallobase entire (Holzenthal 1985, figs 10A-D) .....

A. aragua

6(1) Second article of inferior appendages present (Holzenthal 1985, fig. 5A) ....7

- $\quad$ Second article of inferior appendages absent (Holzenthal 1985, fig. 16C) ... 14

7(6) Tergum $\mathrm{X}$ with mesal process and paired lateral processes (Holzenthal 1985, figs $5 \mathrm{~A}, 14 \mathrm{~A})$.

- $\quad$ Tergum X without mesal process, lateral processes with apical and subapical spinelike projections (Botosaneanu 1990, figs 1-3)

A. janstockiana

8(7) Second article of inferior appendages short (Holzenthal 1985, fig. 14C) or long, but broad (Holzenthal 1985, fig. 6C)

- $\quad$ Second article of inferior appendages elongate and narrow (Holzenthal 1985, Fig. 7C)

9(8) Phallus without parameres (Holzenthal 1985, fig. 6D) 10

- $\quad$ Phallus with parameres (Holzenthal 1985, figs 14A-D) A. quebrada 
10(9) Second article of inferior appendages short, with apical spine-like seta; lateral process of tergum $\mathrm{X}$ with subapical spine-like seta; phallicata with pair of bifid, spiniferous, lateral extensions (Holzenthal 1986, figs 1A-D) A. spinifera

- $\quad$ Second article of inferior appendages long, but broad, without apical spinelike seta; lateral process of tergum X with several apical spine-like setae; phallicata without lateral, bifid extensions, but phallobase with ventral spinelike process (Holzenthal 1985, figs 6A-D)

11(8) Phallus with parameres (Holzenthal 1985, fig. 5D) or phallobase with sclerotized apical projection bearing a stout spine.

- $\quad$ Phallus without parameres (Holzenthal 1985, figs 11A-D)

A. choco

12(11) Inferior appendage with a prominent (Holzenthal 1985, figs 5A, C) to short mesoventral lobe (Holzenthal 1985, fig. 7C) when viewed ventrally; phallus with parameres (Holzenthal 1985, figs 5D, 7D)

- $\quad$ Inferior appendage without mesoventral lobe (Fig. 1C); phallus without parameres, but phallobase with sclerotized apical projection bearing a stout spine (Fig. 1)

A. real sp. n.

13(12) Lateral process of tergum X U-shaped, tip bifid, bearing small spinelike setae (Holzenthal 1985, figs 5A-D)

A. napo

- $\quad$ Lateral process of tergum X tapered to a sharp terminal point, without spinelike setae (Holzenthal 1985, figs 7A-D)

A. stellata

14(6) Parameres small; inferior appendage with basoventral lobe (Holzenthal 1985, figs $16 \mathrm{~A}-\mathrm{D})$

A. cauca

- $\quad$ Parameres large; inferior appendage without basoventral lobe (Holzenthal 1985, figs 12A-D)

A. ayura

\section{Acknowledgements}

The authors wish to thank the Real-Wallace family for their hospitality and support during our field studies in Ecuador during January of 2015 and for their continued interest in our research. Xavier Amigo, Nature Experience, and Jolanda Huisman also provided very generous support in the field. We thank Dr. Desiree Robertson-Thomson, Ernesto Rázuri-Gonzales, and an anonymous reviewer for their useful suggestions on the manuscript and figures. This research was supported by Minnesota Agricultural Experiment Station projects MIN-17-017 and 17-029. Dr. Juan M. Guayasamín and BIOCAMB (Universidad Tecnológica Indoamérica, Quito, Ecuador) provided laboratory support and facilities during fieldwork. The Ministerio del Ambiente, Ecuador, granted the collecting permit (003-14-1C-FAU-FLO-DNB/MA). This support is gratefully acknowledged. 


\section{References}

Blahnik RJ, Holzenthal RW (2004) Collection and curation of Trichoptera, with an emphasis on pinned material. Nectopsyche, Neotropical Trichoptera Newsletter 1: 8-20.

Blahnik RJ, Holzenthal RW, Prather AL (2007) The lactic acid method for clearing Trichoptera genitalia. In: Bueno-Soria J, Barba-Álvarez R, Armitage BJ (Eds) Proceedings of the 12th International Symposium on Trichoptera. The Caddis Press, Columbus, Ohio, 9-14.

Botosaneanu L (1990) A second Antillan species of Amphoropsyche Holzenthal, 1985 (Trichoptera, Leptoceridae). Bijdragen tot de Dierkunde 60: 319-322.

Botosaneanu L (1991) Remarkable double androconial systems in some West Indian Trichoptera. Entomologische Berichten 51: 64-68.

Botosaneanu L (1994) Les Trichoptères de la Guadeloupe. Annales de la Société Entomologique de France (NS) 30: 33-54.

Botosaneanu L, Alkins-Koo M (1993) The caddis flies (Insecta: Trichoptera) of Trinidad and Tobago, West Indies. Bulletin de l'Institut Royal des Sciences Naturelles de Belgique, Entomologie 63: 5-45.

Botosaneanu L, Sakal D (1992) Ecological observations on the caddisflies (Insecta: Trichoptera) from Trinidad and Tobago (W. Indies). Revue d'Hydrobiologie Tropicale 25: 197-207.

Botosaneanu L, Thomas A (2005) Nouvelles contributions à la connaissance des Trichoptères de Martinique, avec description de deux espèces nouvelles (Trichoptera). Ephemera 6 (2004): 33-58.

Flint OS, Jr. (1968) Bredin-Archbold-Smithsonian Biological Survey of Dominica, 9. The Trichoptera (Caddisflies) of the Lesser Antilles. Proceedings of the United States National Museum 125: 1-86. https://doi.org/10.5479/si.00963801.125-3665.1

Flint OS, Jr. (1991) Studies of Neotropical caddisflies, XLV: The taxonomy, phenology, and faunistics of the Trichoptera of Antioquia, Colombia. Smithsonian Contributions to Zoology 520: 1-113. https://doi.org/10.5479/si.00810282.520

Flint OS, Jr. (1996) Studies of Neotropical caddisflies LV: Trichoptera of Trinidad and Tobago. Transactions of the American Entomological Society 122: 67-113.

Flint OS, Jr., Sykora JL (1993) New species and records of caddisflies (Insecta: Trichoptera) from the Lesser Antilles, with special reference to Grenada. Annals of Carnegie Museum 62: 47-62.

Holzenthal RW (1985) Studies in Neotropical Leptoceridae (Trichoptera) II: Amphoropsyche, a new genus and species of Leptocerinae from northern South America. International Journal of Entomology 27: 255-269.

Holzenthal RW (1986) Studies in Neotropical Leptoceridae (Trichoptera), a new species of Amphoropsyche, with a redescription of the immature stages of $A$. insularis (Flint). Annals of the Entomological Society of America 79: 251-255. https://doi.org/10.1093/aesa/79.1.251

Holzenthal RW, Rázuri-Gonzales LE (2011) A new species of Amphoropsyche (Trichoptera, Leptoceridae) from Ecuador, with a key to the species in the genus. ZooKeys 111: 59-65. https://doi.org/10.3897/zookeys.111.813 